\title{
43. TEMPERATURES OF HYDROTHERMAL ALTERATION IN DEEP SEA DRILLING PROJECT HOLE 453, WESTERN MARIANA TROUGH ${ }^{1}$
}

\author{
James R. Lawrence, Lamont-Doherty Geological Observatory, Palisades, New York \\ and \\ James H. Natland, Deep Sea Drilling Project, Scripps Institution of Oceanography, La Jolla, California
}

\begin{abstract}
Gabbro-metabasalt polymict breccias cored in Deep Sea Drilling Project Hole 453 are cemented in part by hydrothermal alteration to lower greenschist facies (chlorite-epidote-actinolite) mineral assemblages. Temperature estimates for this alteration, based on oxygen isotope determinations of secondary minerals, are nearly $100^{\circ} \mathrm{C}$ at the top of the breccias and over $200^{\circ} \mathrm{C}$ in a zone of intense alteration near the base.
\end{abstract}

\section{INTRODUCTION}

As part of a larger effort to understand the types of alteration prevalent in island arc-interarc basin settings, we here report the results of oxygen isotope determinations on secondary minerals in an igneous gabbro-metabasalt polymict breccia sequence cored in Hole 453 $\left(17^{\circ} 54.42^{\prime} \mathrm{W}, 143^{\circ} 40.95^{\prime} \mathrm{E}\right)$, in the western Mariana Trough, during Leg 60 . The hole is of special interest, because shipboard descriptions (presented in the Site 453 report for this volume) indicate that in parts of it the gabbro-metabasalt breccias experienced hydrothermal alteration (to chlorite-epidote-actinolite assemblages). Moreover, heat flow in the hole suggests that presentday temperatures near the top of the breccias (which are beneath 450 meters of turbiditic vitric tuff) are near $50^{\circ} \mathrm{C}$ (Uyeda and Horai, this volume).

The principal lithologies cored in the breccia sequence are described in the site report and in Natland (this volume). Compositions of the rocks are given in Wood et al. (this volume) and in Sharaskin (this volume). Here, we simply note that the breccia matrix, which contains pebbles and boulders of both gabbro and metabasalt, is indurated and consists of two types: (1) a reddish cement, made up primarily of calcite, clay minerals, and iron hydroxides, and (2) an entirely chloritized matrix, restricted to a zone about 20 meters thick approximately 60 meters below the top of the sequence. Within this breccia matrix are a single occurrence of drusy quartz, in the topmost piece (Fig. 1), and widely distributed potassium feldspar replacing chips of calcic plagioclase in the matrix and forming creamy, bleached rims around many of the larger gabbro clasts (Fig. 2). These are the minerals we have chosen for oxygen isotope analysis.

Natland (this volume) has described the chemical and mineralogical consequences of hydrothermal alteration in the breccia matrix. The alkali feldspar appears to have replaced plagioclase because of the inability of the

\footnotetext{
${ }^{1}$ Initial Reports of the Deep Sea Drilling Project, Volume 60
}

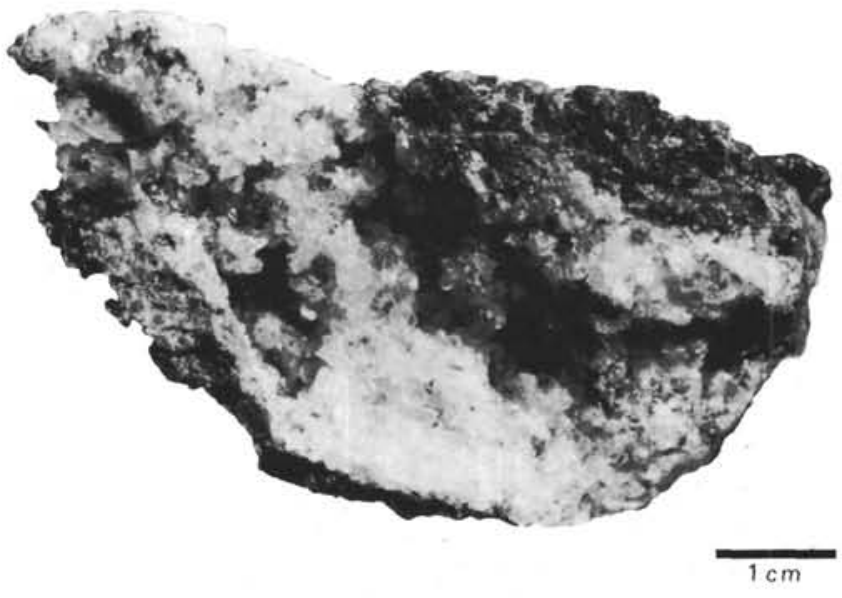

Figure 1. Drusy quartz at the top of the polymict breccia sequence, Sample 453-49-1, Piece 1.

predominant alteration mineral in the matrix-namely, chlorite-to accept $\mathrm{K}, \mathrm{Rb}$, or $\mathrm{Ba}$ in its crystal lattice. Many of the gabbro clasts with this secondary replacement show striking correlative enrichments of $\mathrm{K}, \mathrm{Rb}$, and $\mathrm{Ba}$ (Wood et al., this volume; Natland, this volume). Alkali feldspar formation is most pronounced in the highly chloritized zone (Cores 56 and 57 ) and less so toward the top of the hole. It does not occur in the samples of metamorphosed andesite and dacite below the gabbro breccias (Cores 58-62) or in a sheared gabbro in the final core of the hole (Core 63). Sources for the K, $\mathrm{Rb}$, and $\mathrm{Ba}$ evidently were amphibole and biotite (present in some of the gabbros), metavolcanic rocks, and probably hydrothermal fluids, which by constant flux through the rocks could cause marked enrichments in these elements.

The quartz at the top of the breccias, and calcite in the top few cores of breccia, may have formed as a consequence of proximity to sediments, which consist of siliceous volcanogenic glass derived from the Mariana arc (Packham and Williams, this volume). The biogenic carbonate fraction of the lowermost sediments, however, seems to have experienced almost complete disso- 


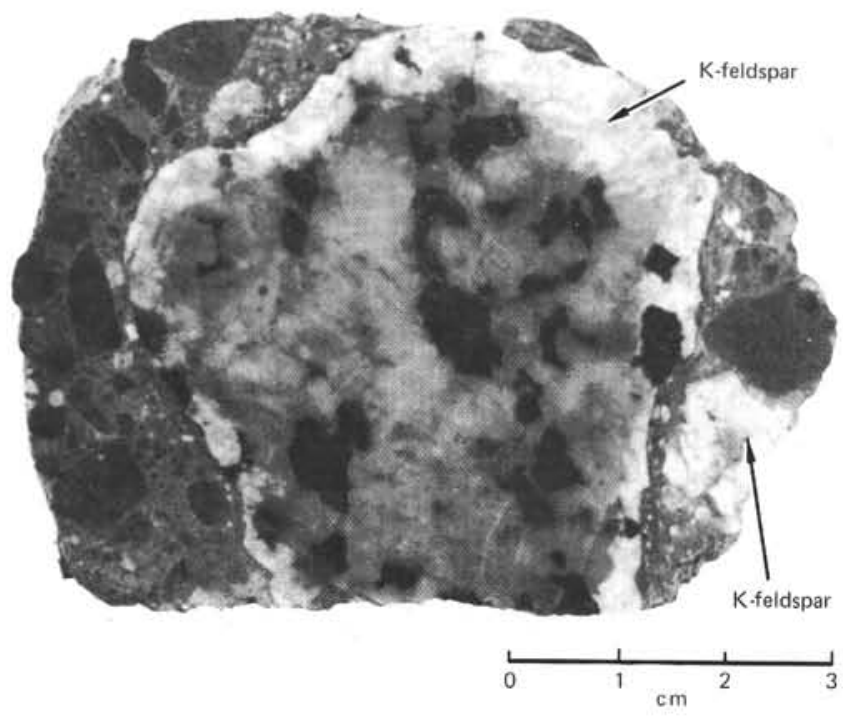

Figure 2. Gabbro sample showing prominent rim of replacement $\mathrm{K}$ feldspar, Sample 453-57-2, Piece 14, 83-89 cm.

lution (Ellis, this volume), possibly as a result of diagenesis, and may have reprecipitated in the uppermost gabbro breccias.

In what follows, the estimates for temperatures, as deduced from alkali feldspars, depend to some extent on the purity of the samples. These were obtained from the breccia matrix. X-ray diffraction patterns from the chloritized zone indicate that the matrix consists of chlorite and potassium feldspar but no plagioclase. One feldspar from this zone was examined using a scanning electron microscope (SEM) (Fig. 3). Although it exhibited the typical polysynthetic twinning of plagioclase, an energy-dispersive X-ray fluorescence analyzer attached to the SEM showed the feldspar to have potassium, aluminum, and silicon but no calcium or sodium. In the chloritized zone at least, replacement to potash feldspar within the breccia matrix has been virtually total.

\section{RESULTS}

Table 1 presents the oxygen isotope analyses of two potassium feldspars and a quartz from Hole 453. To calculate temperatures of formation, we have assumed the minerals to be in isotopic equilibrium with seawater, or with a hydrothermal fluid derived from seawater, which has a $\delta^{18} \mathrm{O}$ equaling $0 \%$ (SMOW). We believe this assumption is justified because of the highly porous nature of the breccias, which would favor high water/rock ratios; because the abundance of $\mathrm{K}$-feldspars in the breccia matrix implies considerable flux of $\mathrm{K}$-bearing fluids through the breccias; and because flux of unmodified seawater is occurring in the breccias today, influencing pore fluid compositions at the base of the vitric tuffs (Gieskes and Johnson, this volume). Alteration at low water/rock ratios can of course modify $\delta^{18} \mathrm{O}$ of seawater-downward for low temperature alteration (Lawrence et al., 1975; Lawrence and Drever, in press) and upward for high temperature alteration (Muehlenbachs and Clayton, 1972; Lawrence et al., 1975)—producing

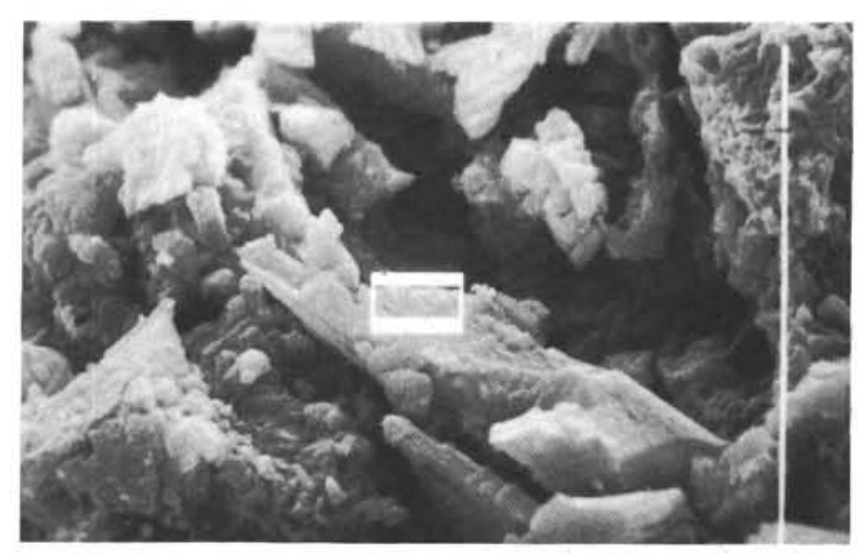

A

$0.1 \mathrm{~mm}$

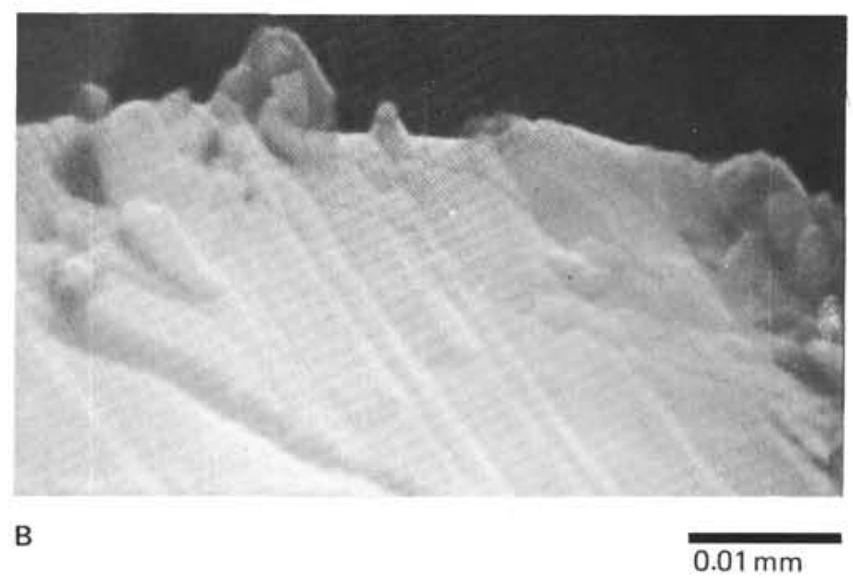

Figure 3. Scanning electron micrographs of feldspar crystals. A. Breccia matrix. Inset is blown up (B) to show relict polysynthetic twinning of a plagioclase grain now completely replaced by $\mathrm{K}$-feldspar. Sample 453-49-1, Piece 1.

Table 1. Oxygen isotope temperatures from hydrothermally altered breccias in DSDP Hole 453.

\begin{tabular}{|c|c|c|c|}
\hline $\begin{array}{c}\text { Sample } \\
\text { (interval in } \mathrm{cm} \text { ) }\end{array}$ & Mineralogy & ${ }^{18} \mathrm{O} \%$ (SMOW) ${ }^{\mathrm{a}}$ & $\begin{array}{c}\text { Temperature } \\
\left({ }^{\circ} \mathrm{C}\right)\end{array}$ \\
\hline $\begin{array}{l}453-49-1,3-5 \\
\# 1\end{array}$ & Quartz & $20.2 \pm 0.3$ & 107 \\
\hline $\begin{array}{l}453-55-1,45-46 \\
\quad \# 2 \mathrm{E}\end{array}$ & $\begin{array}{r}\text { Potassium } \\
\text { feldspar }\end{array}$ & 18.2 & 95 \\
\hline $\begin{array}{l}453-57-2,83-89 \\
\quad \# 13\end{array}$ & $\begin{array}{r}\text { Potassium } \\
\text { feldspar }\end{array}$ & 9.3 & 206 \\
\hline
\end{tabular}

a Analyses were made according to the method of Clayton and Mayeda (1963) but utilized $\mathrm{O}_{2}$ gas in a 6-in. Nuclide mass spectrometer housed at Lamont-Doherty Geological Observatory instead of converting it to $\mathrm{CO}_{2}$. The mass spectrometer reference gas, $\operatorname{tank} \mathrm{O}_{2}$, was calibrated using NBS-28, which was assumed to have a ${ }^{18} \mathrm{O}=+10.0 \%$ ( $\left.\mathrm{SMOW}\right)$, as given in Friedman and Gleason (1973).

temperature estimates higher and lower, respectively, than those based on seawater $\delta^{18} \mathrm{O}$ (Table 1). For our estimates we used the temperature relationships of O'Neil and Taylor (1967) for alkali feldspars and of Clayton et al. (1972) for quartz. Results of the calcula- 
tions indicate that the hydrothermal fluids had temperatures of 90 to $210^{\circ} \mathrm{C}$. The sample of potassium feldspar from the middle of the chloritized zone gave the highest temperature $\left(206^{\circ} \mathrm{C}\right)$, subject to an imprecision of about $5 \%$.

\section{DISCUSSION}

The results confirm the inference that temperatures of hydrothermal alteration were highest in the chloritized portion of the gabbro-metabasalt breccia sequence and lower in the rest of the breccias. The temperature estimate for the chloritized zone is consistent with estimated temperatures for the formation of chlorite in the Reykjanes geothermal system (Kristmannsdottir, 1976) and with experimental results reacting basalt glass with seawater (Mottl and Holland, 1978). We point out that formation of potassium feldspar need not necessarily have occurred at temperatures as high as those prevalent during formation of chlorites or during demagnetization of the gabbros. In fact, comparison with other geothermal localities suggests that formation of minerals such as prehnite, actinolite, and biotite probably occurred at temperatures greater than $300^{\circ}$ (Natland, this volume).

The formation of $\mathrm{K}$-feldspar as a replacement product of calcic plagioclase has been noted before in the DSDP literature (e.g, Site 164 in the central Pacific Basin, Bass et al., 1973; Site 192, Meiji Guyot, Stewart et al., 1973, and Natland, 1973; Sites 315 and 316, Line Islands chain, Kelts and McKenzie, 1976; and Hole 417A, western North Atlantic, Scheidegger and Stakes, 1979). In those instances, however, associated secondary minerals are nontronite, celadonite, mixed layer clays, and iron hydroxides. Bass et al. (1973) and Natland (1973) suggested that to form these minerals, temperatures may have been elevated slightly above that of ambient seawater, although no confirming isotope data was presented in either case. Kelts and McKenzie (1976) suggested that "the replacement phenomena possibly reflect volcanic activity along the [Line Islands] chain"' (p. 789) during the Cretaceous. For Hole 417A, however, oxygen isotope data (Muehlenbachs, 1979) confirm that the alteration was indeed at low temperatures and that its principal distinguishing characteristic was that it was oxidative.

The potassium feldspar in Hole 453 is not of this type. It is most concentrated in a zone of intense chloritization considerably less oxidative than higher in the breccias. It is not associated with clay minerals, which would have competed as sites for potassium. Rather, formation of chlorite evidently left only plagioclase as potential sites for potassium.

The fact that $\mathrm{K}$-feldspar rather than albite formed is surprising in view of the common occurrence of albite among hydrothermally altered seafloor greenstones (e.g., Melson and van Andel, 1966; Cann, 1969; Humphris and Thompson, 1978). It should be noted that the gabbros in Hole 453 consist largely of very calcic plagioclase (anorthite) and thus have very low (0.3-0.5\%) $\mathrm{Na}_{2} \mathrm{O}$ (Wood et al., this volume). Thus there may not have been much Na to mobilize in the first place. The gabbros which exhibit $\mathrm{K}_{2} \mathrm{O}$ enrichment do show a modest enrichment in $\mathrm{Na}_{2} \mathrm{O}$ (Natland, this volume) but not enough to form albite, and the correlation is weak. The SEM observations discussed earlier suggest that any correlation between $\mathrm{K}_{2} \mathrm{O}$ and $\mathrm{Na}_{2} \mathrm{O}$ may be fortuitous, since individual mineral grains transformed to $\mathrm{K}$-feldspar have actually lost $\mathrm{Na}_{2} \mathrm{O}$.

Toward the base of the breccias, however, albitized samples do occur. These are primarily metamorphosed andesites and dacites. Comparison with comparable unaltered calc-alkalic rocks from either the West Mariana Ridge (Mattey et al., in press) or the Mariana Arc (Stern, 1979; Dixon and Batiza, 1979) shows that metamorphosed andesites and dacites in Hole 453 must have lost up to $90 \%$ of their original $\mathrm{K}_{2} \mathrm{O}$ during transformation to albitized greenstones (Natland et al., this volume). Smaller losses in $\mathrm{K}_{2} \mathrm{O}$ among originally low$\mathrm{K}_{2} \mathrm{O}$ seafloor basalts altered to greenstone were noted by Cann (1969) and Humphris and Thompson (1978). Metavolcanic rocks, then, may have been a source for some of the $\mathrm{K}_{2} \mathrm{O}$ in the altered gabbro breccias. Formation of albite in such rocks below the gabbro breccias may actually have acted to fractionate $\mathrm{K}$ from $\mathrm{Na}$, leaving Na-depleted, K-enriched fluids to permeate the gabbros. Finally, the gabbros themselves may have been a very unfavorable substrate for hydrothermal formation of albite, at least compared with seafloor basalts, because they are entirely crystalline, with low original $\mathrm{Na}_{2} \mathrm{O}$, whereas most oceanic greenstones were originally pillow basalts, with glassy or spherulitic textures and $\mathrm{Na}_{2} \mathrm{O}$ contents $>2 \%$. They may consequently have been more receptive to Na-metasomatism, and subjected to a greater degree of it, than the Hole 453 gabbros.

In summary, the formation of $\mathrm{K}$-feldspars among the Hole $\mathbf{4 5 3}$ gabbro breccias evidently resulted from an unusual set of circumstances which rarely combine in the ocean crust. Most significant are the complex composition of the breccias, comingling calc-alkalic rocks both quite enriched and quite depleted in alkali contents, and the firm oxygen isotope evidence that the K-feldspars formed at elevated temperatures-between $90^{\circ}$ and $210^{\circ}$, depending on their location.

\section{ACKNOWLEDGMENTS}

We thank Stan Kling for assistance with the scanning electron microscopy. Support for the X-ray diffraction work was through discretionary postcruise science activities funds assigned to Leg 60 by the Deep Sea Drilling Project. A. C. Adamson and Joris Gieskes reviewed the manuscript.

\section{REFERENCES}

Bass, M. N., Moberly, R. M., Rhodes, J. M., et al., 1973. Volcanic rocks cored in the central Pacific, Leg 17 Deep Sea Drilling Project. In Winterer, E. L., Ewing, J. I., et al., Init. Repts. DSDP, 17: Washington (U.S. Govt. Printing Office), 429-504.

Cann, J. R., 1969. Spilites from the Carlsberg Ridge, Indian Ocean. J. Petrol., 10:1-19.

Clayton, R. N., and Mayeda, T. K., 1963. The use of bromine pentafluoride in the extraction of oxygen from oxides and silicates for isotopic analysis. Geochim. Cosmochim. Acta, 27:45-53.

Clayton, R. N., O'Neil, J. R., and Mayeda, T. K., 1972. Oxygen isotope exchange between quartz and water. J. Geophys. Res., 77: 3057-3067.

Dixon, T. H., and Batiza, R., 1979. Petrology and chemistry of Recent lavas in the northern Marianas: Implications for the origin of island arc basalts. Contrib. Mineral. Petrol., 70:167-181. 
Friedman, I., and Gleason, J. D., 1973. A new silicate inter-comparison standard for ${ }^{18} \mathrm{O}$ analysis. Earth Planet. Sci. Lett., 18:124.

Humphris, S. E., and Thompson, G., 1978. Hydrothermal alteration of oceanic basalts by seawater. Geochim. Cosmochim. Acta, 42: 107-125.

Kelts, K., and McKenzie, J. A., 1976. Cretaceous volcanogenic sediments from the Line Island Chain: Diagenesis and formation of $\mathrm{K}$-feldspar, DSDP Leg 33, Hole 315A and Site 316. In Schlanger, S. O., Jackson, G. D., et al., Init. Repts. DSDP, 33: Washington (U.S. Govt. Printing Office), 789-803.

Kristmannsdottir, H., 1976., Types of clay minerals found in hydrothermally altered basaltic rocks, Reykjanes, Iceland. Jökull, 26:30-39.

Lawrence, J. R., and Drever, J. I., in press. Evidence for coldwater circulation at DSDP Site 395: Isotopes and chemistry of alteration products. J. Geophys. Res.

Lawrence, J. R., Gieskes, J. M., and Broecker, W. S., 1975. Oxygen isotope and cation composition of DSDP pore waters and the alteration of Layer II basalts. Earth Planet. Sci. Lett., 27:1-10.

Mattey, D. P., Marsh, N. G., and Tarney, J., in press. The geochemistry, mineralogy, and petrology of basalts from the West Philippine and Parece Vela Basins, and from the Palau-Kyushu and West Mariana Ridges, Deep Sea Drilling Project Leg 59. In Kroenke, L., Scott, R., et al., Init. Repts. DSDP, 59: Washington (U.S. Govt. Printing Office), 753-800.

Melson, W. G., and van Andel, Tj. H., 1966. Metamorphism in the Mid-Atlantic Ridge, $22^{\circ} \mathrm{N}$ latitude. Mar. Geol., 4:165-186.

Mottl, M. J., and Holland, H. D., 1978. Chemical exchange during hydrothermal alteration of basalt by sea water-I. Experimental results for major and minor components of sea water. Geochim. Cosmochim. Acta, 42:1103-1115.
Muehlenbachs, K., 1979. The alteration and aging of the basaltic layer of the sea floor: Oxygen isotope evidence from DSDP/IPOD Legs 51, 52, and 53. In Donnelly, T., Francheteau, J., Bryan, W., Robinson, P., Flower, M., Salisbury, M., et al., Init. Repts. $D S D P, 51,52,53$, Pt. 2: Washington (U.S. Govt. Printing Office), 1159-1167.

Muehlenbachs, K., and Clayton, R. N., 1972. Oxygen isotope geochemistry of submarine greenstones. Can. J. Earth Sci., 9: 471-478.

Natland, J. H., 1973. Basal ferromanganoan sediments from DSDP Site 183, Aleutian abyssal plain, and Site 192, Meiji Guyot, Northwest Pacific, Leg 19. In Creager, J. S., Scholl, D. W., et al., Init. Repts. DSDP, 19: Washington (U.S. Govt. Printing Office), 629641.

O'Neil, J. R., and Taylor, H. P., Jr., 1967. The oxygen isotope and cation exchange chemistry of feldspars. Am. Mineral., 52:14141437.

Scheidegger, K. F., and Stakes, D. S., 1979. X-ray diffraction and chemical study of secondary minerals from Deep Sea Drilling Project Leg 51, Holes 417A and 417D. In Donnelly, T., Francheteau, J., Bryan, W., Robinson, P., Flower, M., Salisbury, M., et al., Init. Repts. DSDP, 51, 52, 53, Pt. 2: Washington (U.S. Govt. Printing Office), 1253-1263.

Stern, R. J., 1979. On the origin of andesite in the northern Mariana Island Arc: Implications from Agrigan. Contrib. Mineral. Petrol., 68:207-219.

Stewart, R. J., Natland, J. H., and Glassley, W., 1973. Petrology of volcanic rocks recovered on DSDP Leg 19 from the north Pacific Ocean and the Bering Sea. In Creager, J. S., Scholl, D. W., et al., Init. Repts. DSDP, 19: Washington (U.S. Govt. Printing Office), 615-627. 